\title{
- Change in Urban Landuse and its Effect on Natural Drainage System: A Geographical Micro Leveled Study of Bhosari Stream (PCMC)
}

\section{Ramakant Kaspate1 ${ }^{1}$, Avinash Kadam²}

\begin{abstract}
'Research Scholar and Assistant Professor, Annasaheb Waghire College, Otur UGC FDP School of Earth Science, Swami Ramanand Teerth Marathwada University, Nanded, MS, India; ${ }^{2}$ Research Guide and Assistant Professor, School of Earth Science, Swami Ramanand Teerth Marathwada University, Nanded, MS, India.
\end{abstract}

\section{ABSTRACT}

Horizontal and vertical expansion of urban areas has been increasing the rate of exploitation of natural resources, systems and their processes. Now a day, urban landuse has also been changing drastically and primarily affecting the natural set up at very micro level and then spreading it for large areas also. The present investigation is trying to highlight the micro leveled changes by such anthropogenetic activities, basically on physical parameters. For this, the paper mainly focusing on issues of natural drainage system created by change in landuse. By selecting Bhosari stream from Pimpri Chinchwad Municipal Corporation (PCMC) area, the changes in landuse have been identified and studied with the help remote sensing (RS) tools and techniques. The Google Earth Images for 2005 and 2016 have been analyzed, compared and presented by using GIS technique. For this, information from SOI toposheet has also been taken as a base of the study. The selected basin area, a study area has mainly undertaken by PCMC and by the Defense Authority. The changes in land use have also considerable difference in both these areas. But the effects of such changes have observed differently. In short, specifically in PCMC area, the drastic changes in morphometric systems have been noticed like vanishing the upper order streams, displacement of channel, change in pattern of slope and deposition etc. Because of unnatural changes in drainage, most of the urban places have facing natural calamities. It is therefore necessary to maintain the natural processes and systems particularly in the urban area

Key Words: Urbanization, Drainage, Land use, GIS and RS techniques, Morphometric changes, Micro Leveled study

\section{INTRODUCTION}

At global level, cities are growing with their population and infrastructural, unpredicted and unplanned nature (Bingqing and Qihao, 2011). UNO 2011 has rightly predicted that the world's urban population shared about 52 per cent to the total population. Urbanization have worldwide phenomenon where all mega cities are rapidly developing due to various factors including population increases, industrialization and rural-urban migration (Kadam, 1999 and Das et al, 2012). As per 2011 census, in Maharashtra urban population is 15.99 per cent and Pune District urban population 60.9 per cent. Now a day, urban growth has also changed land use and land cover (Bhagawat, 2011; Adil and Rafiq, 2014). Pimpri Chinchwad city has also growing very fast. Growth of urban areas has increasing the rate of exploitation of natural process, system and resources (Kadam, 2002). This urban change has triggered number of geo-environmental problem at many scales such as loss of natural drainage system, natural drainage flow, loss of upper stream order, decline in water quality etc. The increase in urban population density and built up areas directly or indirectly affects on river and small stream i.e. locally known as an Odha (Noorazuan et al, 2003; Kadam et al, 2013). The land use maps have used to provide information on the type, location, spatial, distribution and extend of land use and land cover. These changes are very useful for policy makers, particularly for town planners (Jieying et al, 2005; Golam et al, 2008). The present investigation has mainly trying to identify and explain the cause-effect relationship of such changes at the following study area.

\section{Corresponding Author:}

Avinash Kadam, Research Guide and Assistant Professor, School of Earth Science, Swami Ramanand Teerth Marathwada University, Nanded, MS, India; E-mail: askadam505@gmail.com.

ISSN: 2231-2196 (Print)

Received: 12.04 .2017
ISSN: 0975-5241 (Online)

Revised: 27.04 .2017
DOI: http://dx.doi.org/10.7324/IJCRR.2017.9102

Accepted: 13.05 .2017 


\section{The Study Area}

The study area is a part of PCMC in the Pune district state of Maharashtra (India). PCMC lies between $18^{\circ} 33^{\prime}$ to $18^{\circ} 43^{\prime}$ North latitude and $73^{\circ} 42^{\prime}$ to $73^{\circ} 56^{\prime}$ 'East longitude. The Bhosari stream $($ Odha $)$, the prime study area is a small part of the PCMC. The extents of this study area are from $18^{\circ} 35^{\prime} 04^{\prime \prime}$ to $18^{\circ} 38^{\prime} 52^{\prime \prime}$ North latitude and $73^{\circ} 49^{\prime} 33^{\prime \prime}$ to $73^{\circ} 51^{\prime} 38^{\prime \prime}$ East longitude. The study area divided in two parts that is under PCMC boundary and under central defence authority as shown in the figure 1 .

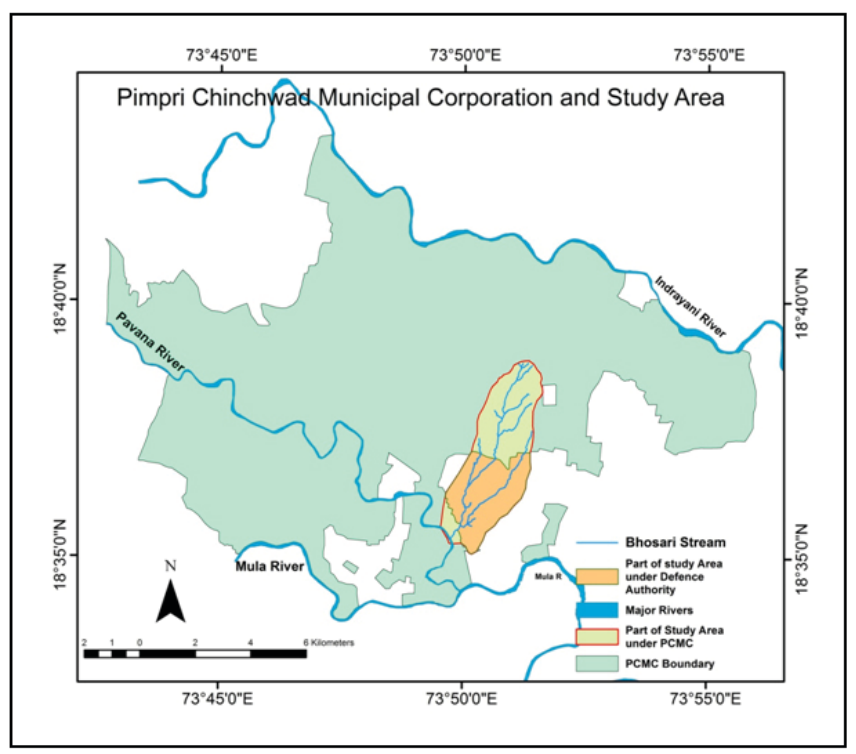

Figure 1: The Study Area.

\section{METHODOLOGY}

It is necessary to compare the changes in land use - land cover (LULC), at least for recent years. It is therefore LULC classification for the PCMC has been worked, based primarily on Google Earth Image dated 20 January 2005 and 17 January 2016. These images has been digitized with the help of simple computer based tools and techniques. The studies of landscape patterns and spatial statistics have also been carried out by using suitable GIS software. In this study, the urban built-up area has classified in residency, commercial, industry, slum, school, temporary huts, and water bodies.

\section{RESULTS}

As mentioned in the methodology, the images have been analysed for the years 2005 and 2016. It is clearly showing the change in LULC. The actual change in areas under major classes of LULC has also been measured and tabulated in the table 1 and 2 with their per cent change. As the area is under two authorities, the drastic change has been observed in PCMC area than that of the area under defense. In both the areas, the open area has occupied by the other purposes. Decrease in the LULC has observed only in case of open land. Actually, the open land was covered by some sort of moderately dense forest and scrubs on or before 2005. Then after the tree cover and even scrubs has also been ruined with fast rate. Now a day, the remaining open land has very rare scrubs and small trees. It means that at both end, the reduction in area and change in vegetation cover has also been noticeable with negative remarks in the environmental contests.

The PCMC area occupying about 7.3616 sq.km area of this selected catchment area of the stream. Table 1 devoted to show the actual general land use and per cent change in it with micro LULC classes of study area. As discussed above, excluding open land, all the classes has increased their land under use. There are three main purposes i.e. residential, industrial and commercial use, which has encroached mainly on open land and other natural land uses. It has also observed at very micro level that the denseness of such purposes has reached up to an optimum to over pressured level. In case of slums, the change in area has just 0.12 per cent but the rowdiness and open areas within and between the slums even for internal paths has also observed to be as at the vanishing stage. Likewise all other purposes e.g. residential, commercial, industrial, etc have been creating high level pressure and extending with drastic movements. It results to damage natural things with decreasing open land.

Table 1: Change in Land use of PCMC Area

\begin{tabular}{|c|c|c|c|c|c|}
\hline \multirow[t]{2}{*}{ Classes } & \multicolumn{2}{|c|}{ Area For Year 2005} & \multicolumn{2}{|c|}{ Area For Year 2016} & \multirow{2}{*}{$\begin{array}{c}\text { Difference } \\
\text { (in per cent) }\end{array}$} \\
\hline & $\begin{array}{c}\text { Area } \\
(\mathrm{sq} . \mathrm{km} .)\end{array}$ & $\begin{array}{l}\text { Proportion } \\
\text { (in per cent) }\end{array}$ & $\begin{array}{c}\text { Area } \\
(\mathrm{sq} . \mathrm{km} .)\end{array}$ & $\begin{array}{l}\text { Proportion } \\
\text { (in per cent) }\end{array}$ & \\
\hline Commercial & 0.0958 & 1.30 & 0.1318 & 1.79 & 0.49 \\
\hline Huts & 0.0356 & 0.48 & 0.0513 & 0.70 & 0.21 \\
\hline Industry & 0.2585 & 3.51 & 0.3245 & 4.41 & 0.90 \\
\hline Residential & 0.8670 & 11.78 & 1.0588 & 14.38 & 2.60 \\
\hline School & 0.0073 & 0.10 & 0.0228 & 0.31 & 0.21 \\
\hline Slum & 0.0349 & 0.47 & 0.0436 & 0.59 & 0.12 \\
\hline Open Area & 6.0623 & 82.35 & $5 \cdot 7288$ & 77.82 & -4.53 \\
\hline Total Area & $7 \cdot 3616$ & 100.00 & 7.3616 & 100.00 & \\
\hline
\end{tabular}




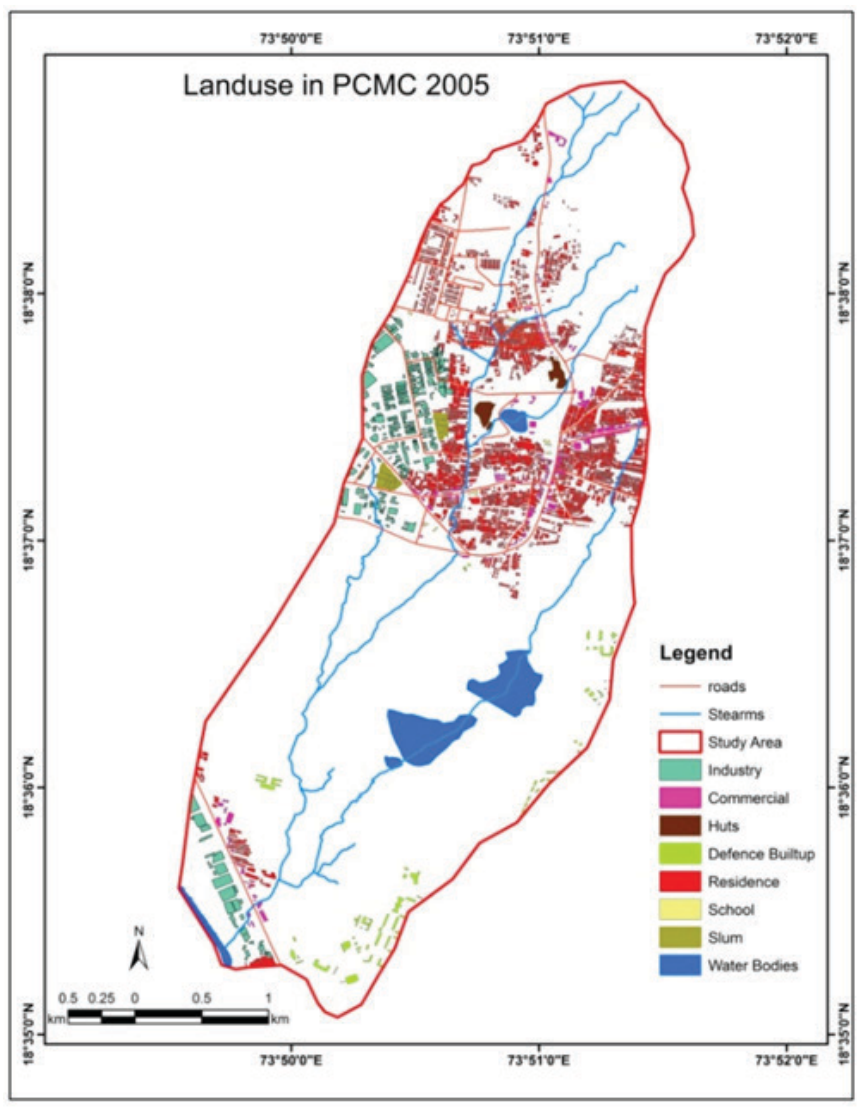

Figure 2: Land use in PCMC 2005

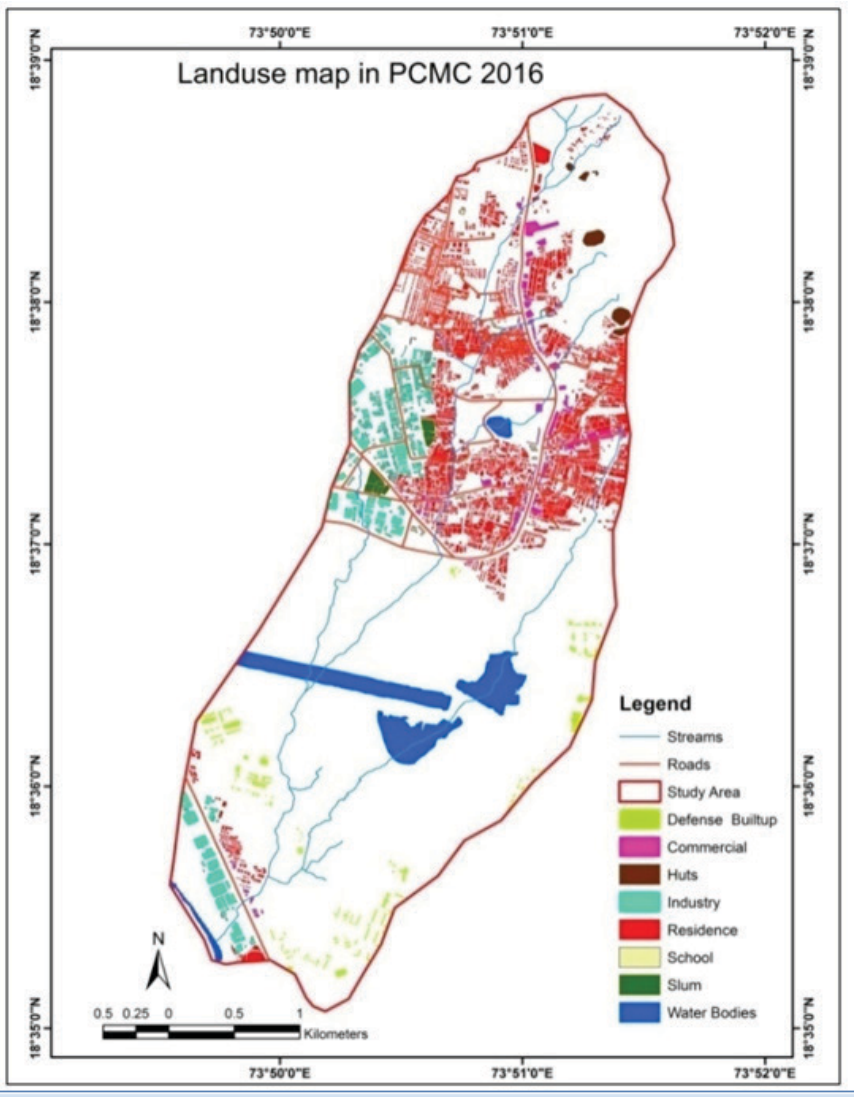

The defense authority is occupying about $6.0040 \mathrm{sq} . \mathrm{km}$ area from the study area. Here also open land has reduced with 3.16 per cent but it converted mainly in to water bodies. The built up area has also occupied the open land, but not as like as crowning nature.

\section{Table 2: Change in Land use of Defence Area}

\begin{tabular}{|c|c|c|c|c|c|}
\hline \multirow[t]{2}{*}{ Classes } & \multicolumn{2}{|c|}{$\begin{array}{c}\text { Area For Year } \\
\quad 2005\end{array}$} & \multicolumn{2}{|c|}{ Area For Year 2016} & \multirow{2}{*}{$\begin{array}{l}\text { Difference } \\
\text { (in per } \\
\text { cent) }\end{array}$} \\
\hline & $\begin{array}{l}\text { Area } \\
\text { (sq. } \\
\text { km.) }\end{array}$ & $\begin{array}{l}\text { Propor- } \\
\text { tion } \\
\text { (in per } \\
\text { cent) }\end{array}$ & $\begin{array}{l}\text { Area } \\
\text { (sq. } \\
\text { km.) }\end{array}$ & $\begin{array}{l}\text { Proportion } \\
\text { (in per } \\
\text { cent) }\end{array}$ & \\
\hline $\begin{array}{l}\text { Defence } \\
\text { Built up }\end{array}$ & 0.0579 & 0.96 & 0.1090 & 1.82 & 0.85 \\
\hline $\begin{array}{l}\text { Water } \\
\text { Bodies }\end{array}$ & 0.3540 & 5.90 & 0.4925 & 8.20 & 2.31 \\
\hline $\begin{array}{l}\text { Defence } \\
\text { Open } \\
\text { Area }\end{array}$ & $5 \cdot 5921$ & 93.14 & 5.4025 & 89.98 & -3.16 \\
\hline $\begin{array}{l}\text { Total } \\
\text { Area }\end{array}$ & 6.0040 & 100.00 & 6.0040 & 100.00 & \\
\hline
\end{tabular}

\section{DISCUSSION}

Urban built up area has increased and at some places, manmade activity has been affecting the natural drainage systems. Such as village Bhosari Goan Lake stream at middle part are replaced at built up and other purposes. Near Bhairavanath School first order stream flow change by built up area. In middle part of study area near Landewadi slum area industrial built up replace stream. Goan lake stream raw material dump in stream basin and change flow direction of stream. At defense area newly constructed water pool stream flow doing narrow below water pool. In this study area there is 22 first order streams, 2 second order stream and one third order stream.

\section{CONCLUSION}

The present study has revealed that GIS techniques have significant prospective for mapping and monitoring of land use. There is major decrease of open area and increase in residential, commercial, industrial area from year 2005 to year 2016. The rapid urban growth has transformed most of the open land into residential area. In short, specifically in PCMC area, the drastic changes in vanishing the upper order streams, displacement of channel, change in pattern of slope and deposition.

Figure 3: Land use in PCMC 2016. 


\section{ACKNOWLEDGEMENT}

Authors are very thankful to research scholars whose article and references are reviewed for this research paper and thankful to, editors and publishers of that articles.

\section{REFERENCES}

1. Aadil, M. and Rafiq, A. (2014). Changes in land-use/land-cover dynamics using geospatial techniques: A case study of Vishav drainage basin. Journal of Geography and Regional Planning, 7(4), pp. 69-77.

2. Bhagawat, Rimal (2011). Application of Remote Sensing and GIS, Land Use/Land Cover Change in Kathmandu Metropolitan City, Nepal. Journal of Theoretical and Applied Information Technology, 26 (2), ISSN 1992-8645 pp. 80-86 (www.jatit.org).

3. Bingqing, L. and Qihao, W. (2011). Assessing Urban Environmental Quality Change of Indianapolis, United States, by the Remote Sensing and GIS Integration. IEEE Journal of Selected Topics in Applied Earth Observations And Remote Sensing, 4 (1), pp. 43-55.

4. Cheng-fan LI and Jing-yuan Yin (2011). Research Overview on Urban Land Use Change Based on Remote Sensing Images. International Journal of Environmental Science and Development, 2(1), pp. 45-48.
5. Das, S.; Mali, S. and Misra, A. (2012). Urban Land use/LandCover Change Detection Analysis of Aurangabad City Using Geoinformatics Techniques. International Journal of Scientific and Research Publications, 2(9), pp. 1-5.

6. Golam, R.; Deanna, A. and Sirajul, I. (2008). City Growth with urban Sprawl and Problems of Management. 44 ${ }^{\text {th }}$ ISOCARP Congress, pp. 1-11.

7. Jieying, X.; Yanjun, S. and Jingfeng, G. (2005). Evaluating urban expansion and land use change in Shijiazhuang, China, by using GIS and remote sensing. Landscape and Urban Planning, pp. 69-80.

8. Kadam, A.; Bhosle, A. and Avhad, B. (2013). Drainage Characteristics and its Relation to Soil $\mathrm{pH}$ and EC of Kurunda River Basin of Maharashtra. 3(6), pp. 35-37.

9. Kadam, Avinash and Saptarshi, Praveen (1999). Comparative Study of Two Urban Centres in the Eastern Pune District (Maharashtra). Uttar Pradesh Geographical Journal, 8(1), pp. 1-5.

10. Kadam, Anuradha; Kadam, Avinash and Saptarshi, Praveen (2002).Impact of Brick Industry on Physical Environment. Maharashtra Bhugolshastra Shnshodan Patrika, 16(1), pp. 179 - 184.

11. Noorazuan, M. Ruslan, R. and Hafizan, J. (2003). GIS Application in Evaluating Land Use-Land Cover change and its Impact on Hydrological Regime in Langat River Basin, Malaysia. Map Asia Conference, pp 1-11. 